\title{
Microbial Assessment of Tomatoes (Lycopersicon esculentum) Sold at Some Central Markets in Ghana
}

\author{
Forson Akua Obeng ${ }^{\mathbb{D}},{ }^{1}$ Pokuaa Belinda Gyasi, ${ }^{1}$ \\ Michael Olu-Taiwo, ${ }^{1}$ and F. Patrick Ayeh-kumi ${ }^{1,2}$ \\ ${ }^{1}$ Department of Medical Laboratory Science, School of Biomedical and Allied Health Sciences, College of Health Sciences, \\ University of Ghana, Legon, Accra, Ghana \\ ${ }^{2}$ Department of Medical Microbiology, School of Biomedical and Allied Health Sciences, College of Health Sciences, University of Ghana, \\ Legon, Accra, Ghana \\ Correspondence should be addressed to Forson Akua Obeng; obeng.akua@yahoo.com
}

Received 9 May 2018; Accepted 10 October 2018; Published 29 November 2018

Guest Editor: Marta Laranjo

Copyright ( 2018 Forson Akua Obeng et al. This is an open access article distributed under the Creative Commons Attribution License, which permits unrestricted use, distribution, and reproduction in any medium, provided the original work is properly cited.

Background. Tomato (Lycopersicon esculentum) has a high water content which predisposes it to spoilage by pathogenic bacteria that can pose significant health threats to consumers. Aim. The study aimed to determine the various pathogenic bacteria associated with tomatoes sold in some central markets in the Accra Metropolis. Method. A total of 120 tomatoes were sampled, out of which 60 fresh, firm, undamaged tomatoes and 60 spoilt tomatoes were analysed. Cut portions of the fresh and spoilt tomatoes were swabbed with sterile swabs and cultured on Blood agar, Nutrient agar, and MacConkey agar. The antibiogram of bacterial isolates was determined by Kirby-Bauer disc-diffusion method. Results. Out of the 120 tomatoes analysed, a total of 66 bacterial isolates were recovered, $68.2 \%$ were associated with spoilt tomatoes, and $31.8 \%$ were from fresh tomatoes. Klebsiella sp. (34.8\%), Enterobacter sp. (24.2\%), and Citrobacter sp. (7.6\%) were the predominant bacteria isolated. Agbogbloshie market (36.4\%) had both fresh (18.2\%) and spoilt (18.2\%) tomatoes contaminated, whilst Makola market (31.8\%) had a higher spoilt (30.3\%) tomatoes contaminated. Although none of the isolates expressed resistance to ciprofloxacin, resistance was found for ampicillin (63.1\%), tetracycline (60.1\%), and cefuroxime (59.1\%). Conclusion. Varying levels of antibiotic resistance bacteria amongst tomatoes sold at various markets were found. Contamination might have been caused by poor sanitation, improper handling or transportation from the farms to the markets. The presence of antibiotic resistance bacteria amongst tomatoes raises concern on public health risks associated with the consumption of fresh tomatoes.

\section{Introduction}

Tomato (Lycopersicon esculentum) is a perishable vegetable widely cultivated and consumed worldwide $[1,2]$. It is rich in nutrients, vitamins, dietary fibres, and phytochemicals [3-5]. It is known to be a very profitable crop that provides high returns for small scale farmers in most developing countries [6]. Due to its nutritive value, taste, affordability, and accessibility, there has been an increase in demand by consumers [7]. However, isolation and identification of microorganisms that are associated with spoilage of tomatoes have gained some research focus [8].

In most developing countries, microbial infestation of tomatoes can occur during the harvesting period, postharvesting, handling, storage, transportation, and processing by customers $[9,10]$. Baiyewu et al. [11] have also reported that another means of bacterial contamination is by exposing them on benches and baskets in the open markets for customers. The proliferation of bacteria more especially in damaged tomatoes could be considered to be more harmful when such contaminated tomatoes are consumed in improperly cooked food [2].

Some studies have been carried out on bacteria associated with tomatoes and tomato products in some countries. A study carried out by Ajayi [12] in the United State has revealed that Clostridium sp., Staphylococcus sp., and Bacillus sp. were predominant bacteria isolated from both canned and raw tomatoes. In India, a study carried out on tomato puree 


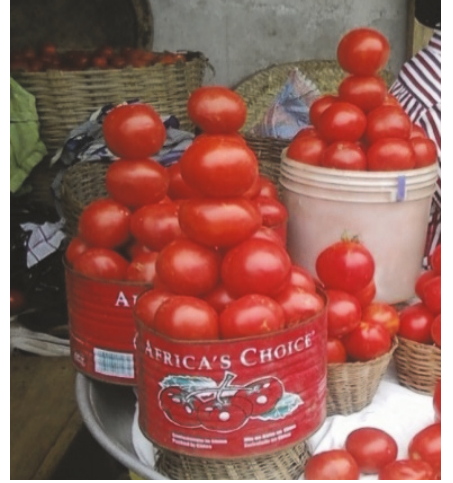

(a) Fresh tomatoes

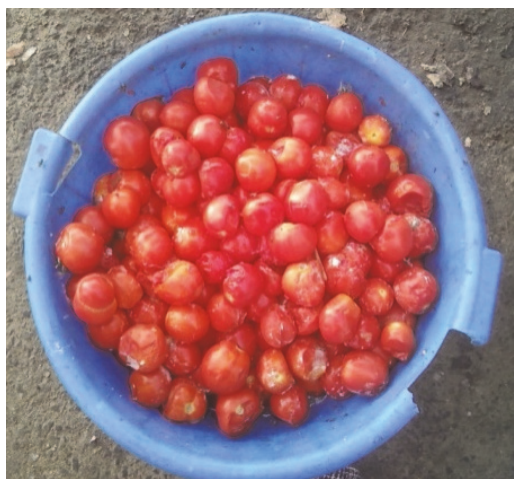

(b) Spoilt tomatoes (these tomatoes are often sold at reduced prices to interested consumers).

FIGURE 1: Pictures of some displayed tomatoes in markets.

revealed the presence of Klebsiella sp., Proteus mirabilis, Vibrio sp., and Pseudomonas sp. [13]. In Nigeria, Wogu and Ofuase [14] isolated Bacillus subtils, Klebsiella aerogenes, Pseudomonas aeruginosa, Salmonella typhi, Proteus mirabilis, and Staphylococcus aureus from spoilt tomatoes in Benin City. A similar study also revealed high levels of Staphylococcus sp. (22.5\%), Bacillus sp. (20\%), and Escherichia coli (15\%) in Lagos State, Nigeria [15]. In Ghana, limited information is available on the types of pathogenic bacteria associated with tomatoes sold in markets in Accra, Ghana. This study aimed to isolate and identify pathogenic bacterial agents associated with two different grades of raw tomatoes (fresh and spoilt) sold in three central markets in Accra.

\section{Methodology}

\subsection{Study Area}

2.1.1. Sample Collection. An experimental study was carried out by randomly purchasing tomatoes from different sellers at three different markets (Agbogbloshie, Makola, and Kaneshie) in Accra. These markets were selected because they are major markets in the region where tomatoes are sold at cheaper prices to consumers.

A total of 120 tomatoes were randomly purchased from the three markets in Accra. In each market, 20 fresh (Figure 1(a), firm and undamaged) and 20 spoilt (Figure 1(b), damaged and spoilt) tomatoes were purchased. Ten sellers were selected from each market and two fresh and spoilt tomatoes each were purchased. Samples were separately packaged into different sterile containers, labelled, and transported to the laboratory immediately for bacteriological analysis. The elapsed time between sample collection and analysis did not exceed $2 \mathrm{hrs}$.

2.1.2. Laboratory Analysis. Tomatoes was analysed using Ugwu et al's [16] method. Briefly, fresh tomatoes were individually washed with sterile water before the tomatoes were cut into two equal halves (this was carried out because this is a common practice by consumers before food preparation). Aseptically, a sterile swab stick was used to swab the cut interior of the tomatoes. The swabs were then streaked onto Blood agar (Oxoid, UK), Nutrient agar (Oxoid, UK), and MacConkey agar (Oxoid, UK) and incubated at $37^{\circ} \mathrm{C}$ for $18-$ 24 hours.

For the spoilt tomatoes, a sterile swab was used to take samples from the spoilt portion of the tomatoes and this was streaked onto Blood agar, Nutrient agar, and MacConkey agar before incubation at $37^{\circ} \mathrm{C}$ for $18-24 \mathrm{hrs}$.

2.1.3. Identification of Organisms. After incubation, the colonies of the different culture media were examined and recorded based on the shape, colour, border, texture, and general appearance of individual bacterial colonies on each plate, and single representative colony was Gram stained [17]. Gram staining was done to reveal the characteristic group and arrangement of the cells. Biochemical tests (indole test, methyl red test, Voges-Proskauer (VP) test, citrate test, oxidase test, coagulase test, and sugar fermentation test) were then carried out for the identification of bacterial isolates.

2.1.4. Susceptibility Testing. Antibiogram of all bacterial isolates were carried out using Kirby-Bauer disk diffusion method [18] to ampicillin (10 $\mu \mathrm{g})$, chloramphenicol $(10 \mu \mathrm{g})$, cefotaxime $(30 \mu \mathrm{g})$, ceftriaxone $(30 \mu \mathrm{g})$, gentamicin $(10 \mu \mathrm{g})$, cefuroxime $(30 \mu \mathrm{g})$, meropenem $(10 \mu \mathrm{g})$, amikacin $(30 \mu \mathrm{g})$, cotrimoxazole $(25 \mu \mathrm{g})$, ciprofloxacin $(5 \mu \mathrm{g})$, and tetracycline $(10 \mu \mathrm{g})$. These antibiotics are commonly used for the treatment of bacterial infections in the general populace [19].

Briefly, stored isolates were subcultured onto horse blood agar plates $\left(37^{\circ} \mathrm{C}, 18 \mathrm{hrs}\right.$.) and individual colonies were suspended in saline to a turbidity equivalent to $0.5 \mathrm{McF}$ arland standard. The suspensions obtained were then streaked on Mueller-Hinton agar plate (Oxoid, UK) using sterile swab sticks. The paper discs were gently but firmly placed on the inoculated plates before the plates were incubated at $37^{\circ} \mathrm{C}$ for $18-24 \mathrm{hrs}$. After incubation, zones of inhibition were measured and interpreted according to Clinical and 
TABLE 1: Distribution of the bacteria isolates in different grades of tomatoes from three major markets in Accra.

\begin{tabular}{|c|c|c|c|c|}
\hline \multirow[b]{3}{*}{ Isolates } & \multicolumn{3}{|c|}{ Fresh tomatoes } & \multirow[b]{3}{*}{ Total (\%) } \\
\hline & \multicolumn{3}{|c|}{ Markets (no. of sampled tomatoes) } & \\
\hline & Agbogbloshie $(n=20)$ & Kaneshie $(n=20)$ & Makola $(n=20)$ & \\
\hline Bacillus sp. & 0 & 2 & 0 & \\
\hline Citrobacter sp. & 0 & 0 & 0 & \\
\hline Citrobacter koseri & 0 & 0 & 0 & \\
\hline Enterobacter sp. & 6 & 1 & 0 & \\
\hline Enterobacter cloacae & 0 & 1 & 0 & \\
\hline Klebsiella sp. & 5 & 4 & 1 & \\
\hline Klebsiella oxytoca & 1 & 0 & 0 & \\
\hline Klebsiella pneumoniae & 0 & 0 & 0 & \\
\hline Proteus mirabilis & 0 & 0 & 0 & \\
\hline P. aeruginosa & 0 & 0 & 0 & \\
\hline Shigella sp. & 0 & 0 & 0 & \\
\hline \multirow[t]{3}{*}{ Total (\%) } & $12(18.2)$ & $8(12.1)$ & $1(1.5)$ & $21(31.8)$ \\
\hline & \multicolumn{3}{|c|}{ Spoilt tomatoes } & \\
\hline & \multicolumn{3}{|c|}{ Markets (no. of sampled tomatoes) } & \\
\hline Isolates & Agbogbloshie $(n=20)$ & Kaneshie $(n=20)$ & Makola $(n=20)$ & \\
\hline Bacillus sp. & 0 & 0 & 0 & \\
\hline Citrobacter sp. & 0 & 2 & 3 & \\
\hline Citrobacter koseri & 0 & 0 & 2 & \\
\hline Enterobacter sp. & 3 & 4 & 2 & \\
\hline Enterobacter cloacae & 2 & 0 & 0 & \\
\hline Klebsiella sp. & 2 & 3 & 8 & \\
\hline Klebsiella oxytoca & 3 & 2 & 2 & \\
\hline Klebsiella pneumoniae & 1 & 0 & 0 & \\
\hline Proteus mirabilis & 0 & 1 & 1 & \\
\hline P. aeruginosa & 0 & 0 & 2 & \\
\hline Shigella sp. & 1 & 1 & 0 & \\
\hline Total & $12(18.2)$ & $13(19.7)$ & $20(30.3)$ & $45(68.2)$ \\
\hline Total no. of isolates from fresh and spoilt tomatoes & $24(36.4)$ & $21(31.8)$ & $21(31.8)$ & $66(100 \%)$ \\
\hline
\end{tabular}

Laboratory Standard Institute [18], whilst other break points were sourced from EUCAST [20] (European Committee on Antimicrobial Susceptibility Testing).

The reference strains used for the determination of the MIC values were E. faecalis ATCC 29212 and Staphylococcus aureus ATCC 29213.

2.1.5. Data Analysis. The quantitative data generated from the study was coded and fed into Microsoft Excel and analysed using GraphPad Prism software, version 6. In all cases, $\mathrm{P}$ values less than 0.05 were considered statistically significant. Fisher exact test was carried out to test the significance of prevalence of bacteria in the various markets.

\section{Results}

3.1. Distribution of the Bacteria in Three Central Markets in Accra. Out of the 120 tomatoes purchased from the three markets (Agbogbloshie, Kaneshie, and Makola), eleven different bacteria were isolated (Table 1). They were Bacillus sp., Enterobacter sp., Citrobacter sp., Klebsiella sp., Shigella sp., Proteus mirabilis, Klebsiella oxytoca, Enterobacter cloacae, Citrobacter koseri, and Klebsiella pneumoniae. Tomatoes sampled from Agbogbloshie market (36.4\%) were the most contaminated in both fresh (18.2\%) and spoilt (18.2\%) tomatoes with similar prevalence of bacterial contamination. In contrast, tomatoes sampled from Kaneshie (31.8\%) had few fresh (12.1\%) and spoilt (19.7\%) tomatoes contaminated, and Makola (31.8\%) market had higher spoilt (30.3\%) tomatoes contaminated.

Significant difference was found between Kaneshie and Makola markets $(\mathrm{p}=0.0021)$ and Agbogbloshie and Makola markets ( $\mathrm{p}=<0.0001)$, when the prevalence of isolated bacteria was evaluated. However, no significant difference was found between Agbogbloshie and Kaneshie markets ( $p$ $=0.5503)$.

3.2. Occurrence of Bacteria in Sampled Fresh and Spoilt Tomatoes. Table 2 shows the percentage distribution of isolates in fresh and spoilt tomatoes purchased from the different markets. Out of a total of 66 isolates isolated, $68.2 \%$ were associated with spoilt tomatoes, whilst $31.8 \%$ were on fresh tomatoes. 
TABLE 2: Total distribution of bacteria isolates in fresh and spoilt tomatoes.

\begin{tabular}{|c|c|c|c|}
\hline \multirow[b]{2}{*}{ Isolates } & \multicolumn{2}{|c|}{ Grade of Tomatoes } & \multirow[b]{2}{*}{ Total (\%) } \\
\hline & Fresh tomatoes & Spoilt tomatoes & \\
\hline Bacillus species & 2 & 0 & $2(3.0)$ \\
\hline Citrobacter species & 0 & 5 & $5(7.6)$ \\
\hline Citrobacter koseri & 0 & 2 & $2(3.0)$ \\
\hline Enterobacter species & 7 & 9 & $16(24.2)$ \\
\hline Enterobacter cloacae & 1 & 2 & $3(4.5)$ \\
\hline Klebsiella species & 10 & 13 & $23(34.8)$ \\
\hline Klebsiella oxytoca & 1 & 7 & $8(12.1)($ \\
\hline Klebsiella pneumoniae & 0 & 1 & $1(1.5)$ \\
\hline Proteus mirabilis & 0 & 2 & $2(3.0)$ \\
\hline P. aeruginosa & 0 & 2 & $2(3.0)$ \\
\hline Shigella species & 0 & 2 & $2(3.0)$ \\
\hline Total & $21(31.8)$ & $45(68.2)$ & $66(100)$ \\
\hline
\end{tabular}

Klebsiella sp. (34.8\%) was the predominant isolates with 10 of the fresh and 13 spoilt tomatoes being positive. Enterobacter sp. (24.2\%) followed with 7 of the fresh tomatoes and 9 of the spoilt tomatoes. Whilst Klebsiella oxytoca (12.1\%) was next with 1 isolate in the fresh tomatoes and 7 in the spoilt ones, Citrobacter sp. (7.6\%) was found in only two fresh tomatoes. Except for Enterobacter cloaca which was found in 1 of the fresh and 2 of the spoilt tomatoes, Bacillus sp. (3\%) was found in 2 of the fresh tomatoes. Shigella sp., Proteus aeruginosa, Proteus mirabilis, and Citrobacter koseri were not isolated from any of the fresh tomatoes but were found in 2 of the spoilt ones, respectively. Finally, the one with the least occurrence was Klebsiella pneumoniae which was found in only one of the spoilt tomatoes.

3.3. Antibiogram. The resistance levels of ten tested antibiotics for all the bacterial isolates are presented in Figure 2. The results for the different bacterial species have been combined to enable comparison. Resistance to ampicillin, amikacin, cotrimoxazole, cefuroxime, chloramphenicol, ceftriaxone, cefotaxime, ciprofloxacin, meropenem, and tetracycline was found in all grades of tomatoes.

In total, resistance to ampicillin (63.6\%), cefuroxime (59.1\%), and tetracycline $(60.1 \%)$ was found to be the highest (Figure 2). However, a slightly lower prevalence was found for cefotaxime, (34.8\%) and ampicillin (37.9\%), ceftriaxone $(28.8 \%)$, chloramphenicol $(24.2 \%)$, and cotrimoxazole (13.6\%). Whilst a very low resistance level was found for gentamicin $(6.1 \%)$ and amikacin $(1.5 \%)$, none of the isolates was resistant to ciprofloxacin.

Furthermore, most of the Citrobacter sp., Klebsiella sp., and Enterobacter sp. were multiresistant to ampicillin, tetracycline, or cefotaxime (Table 3). However, a few Enterobacter sp. (2 isolates), Citrobacter Koseri (1 isolate), and Klebsiella sp. (1 isolate) were resistant to more than five different antibiotics.

\section{Discussion}

The present study reports for the first time varying prevalence of resistant bacteria in sampled tomatoes purchased from the

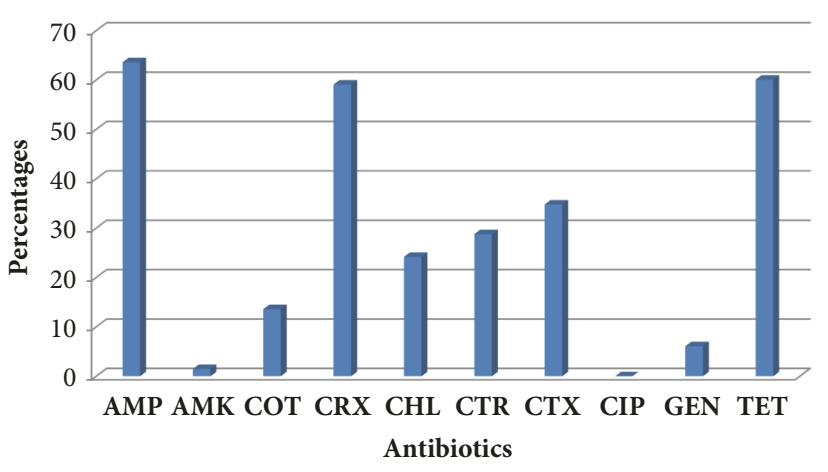

Figure 2: Percentage distribution of resistance pattern of bacteria isolated from tomatoes. $\mathbf{A M P}=$ Ampicillin, $\mathbf{A M K}=$ Amikacin, COT $=$ Cotrimoxazole, $\mathbf{C R X}=$ Cefuroxime, $\mathbf{C H L}=\mathrm{Chloramphenicol}$, CTR=Ceftriaxone, $\quad$ CTX=Cefotaxime, $\quad \mathbf{C I P}=$ Ciprofloxacin, GEN=Gentamicin, and TET $=$ Tetracycline.

different sellers in selected central markets (Agbogbloshie, Kaneshie, and Makola markets) in Accra, Ghana. In contrast to Kaneshie (34.78\%) and Makola (21.74\%) markets, Agbogbloshie (43.48\%) recorded the highest level of contamination. This suggests that Agbogbloshie market is not as hygienic as compared to Makola and Kaneshie markets. The presence of bacteria in the fresh tomatoes bought from these markets may be because they were improperly handled during the sellers' attempts to arrange them for sales [21]. The varying differences in contamination from the three markets could also be as a result of differences in the sources of farm products or wholesale points where the market sellers bought their tomatoes from [22].

In this study, Klebsiella sp. (34.8\%) was the prevalent bacteria isolated from both spoilt tomatoes (19.7\%) and fresh tomatoes (15.2\%). This is in contrast to Ugwu et al.'s [16] study in Nigeria which reported isolation rate of $8.9 \%$ in only spoilt tomatoes and Wogu and Ofuase [16] study from Benin City, Nigeria, with a total isolation rate of $1.6 \%$ for Klebsiella sp. Whilst in Spain, Falomir et al. [23] have isolated Klebsiella pneumoniae and Klebsiella oxytoca in their work on fresh 
TABLE 3: Distribution of Multidrug resistant (MDR) bacteria isolates in fresh and spoilt tomatoes.

\begin{tabular}{lcc}
\hline Isolates (total no. isolated) & No. of MDR isolates & Resistant pattern \\
\hline Citrobacter species (5) & 1 & AMP-TET-CRX \\
& 1 & AMP-CRX-CTD \\
Citrobacter koseri (5) & 2 & AMP-TET-CRX-CTX \\
Enterobacter sp. (16) & 1 & TET-GEN-CRX-CHL-CTX \\
& 1 & AMP-TET-COT-CRX-CHL-CTX \\
& 1 & CRX-CTR-CTX \\
Enterobacter cloacae (3) & 1 & AMP-CRX-CTR-CTX \\
Klebsiella sp. (10) & 1 & AMP-TET-GEN-CRX-CTR-CTX \\
& 1 & AMP-TET-COT-CRX-CHL-CTX \\
Klebsiella oxytoca (8) & 1 & AMP-TET-CRX-CTX \\
& 1 & TET-CRX-CTR-CTX \\
& 1 & AMP-CRX-CTR-CTX \\
Klebsiella pneumonia (1) & 1 & AMP-TET-CRX-CHL-CTR-CTX \\
Proteus mirabilis (2) & 1 & AMP-CRX-CTX \\
\hline
\end{tabular}

$\mathrm{TET}=$ Tetracycline, $\mathrm{COT}=$ Cotrimoxazole, $\mathrm{GEN}=$ Gentamicin, $\mathrm{CRX}=$ Cefuroxime, $\mathrm{CHL}=$ Chloramphenicol, $\mathrm{CTX}=\mathrm{Cefotaxime}, \mathrm{CTR}=\mathrm{Ceftriaxone}, \mathrm{MEM}=$ Meropenem, $\mathrm{AMK}=$ Amikacin, $\mathrm{CIP}=$ Ciprofloxacin, and $\mathrm{AMP}=\mathrm{Ampicillin}$.

vegetables; the varying prevalence of Klebsiella isolates in the different countries could be because of varying human activities associated with postharvest practices before the tomatoes are displayed for sale in the different countries. In addition, Klebsiella sp. are ubiquitous organisms that can be found in the environment, animals, and humans [24, 25]. The bacteria could have gained access to the tomatoes during postharvest period involving poor transportation and storage facilities on the field with stomata that have openings, cracks, or surface injuries as reported by Lemma et al. [6].

In this study, prevalence for Enterobacter sp. (24.2\%) was found to be slightly higher than the $21.4 \%$ reported by Adebayo-Tayo et al. [26], in Uyo Metropolis, Nigeria. Their presence in tomatoes may be due to handling practices by the vendors [27]. The high incidence of Klebsiella sp. and Enterobacter sp. is an indication of human contact, since improper handling of tomatoes during market days may have introduced these organisms into the tomatoes [28].

The presence of Enterobacter sp., Citrobacter sp., Proteus mirabilis, and Bacillus sp. in this study is in conformity with Ogundipe et al. [15], which isolated similar bacteria with percentages of $12.5 \%, 2.5 \%, 2.5 \%$, and $20.0 \%$, respectively, from tomatoes in Lagos State, Nigeria. However, Citrobacter sp. was found to be $7.6 \%$ in this study which is lower than the 30\% reported by Mahamud et al. [29], in Northern Nigeria on tomatoes. Citrobacter sp. and Citrobacter koseri are often present in soils, water, or wastewater and can cause infections in the urinary tract and sepsis in humans. Their presence in the tomatoes could have been introduced from the soil in which the tomatoes were planted or as a result of irrigation with contaminated wastewater. The percentage of Bacillus sp. isolated in this study was $3.0 \%$, which is lower than $59.1 \%$ reported by Wogu and Ofuase [14] in previous study on tomatoes in Benin City, Nigeria. The difference in prevalences may be associated with varying incidence of Bacillus sp. spores in the environment [30]. In addition, Bacillus sp. are resistant to killing by high temperatures of the sun's ultraviolet rays because of the endospores, hence their bacterial load in the tomatoes. In this study, Proteus mirabilis isolated confirms with a previous work done by Garg et al. [14] in India with tomatoes. Proteus mirabilis is an opportunistic pathogen in the normal intestinal flora and they may be associated with community-acquired infection [31]. It is widely distributed in contaminated soil and water in the natural environment and can easily find its way into foodstuffs which are not well handled.

The presence of Shigella sp. (3.0\%) in only the spoilt tomatoes is an indication that the tomatoes may have been exposed to faecal-contaminated water or manure during cultivation [32]. Shigella sp. isolated in this study is in contrast to Adebayo-Tayo et al.s [26] study in Uyo Metropolis, Nigeria, which reported no Shigella sp. Shigella sp. can contaminate tomatoes when they are exposed to faecal-contaminated water or improper hygiene prior to handling of the tomatoes [33].

Furthermore, most of the isolates were susceptible to gentamicin $(93.9 \%)$ and amikacin $(98.5 \%)$, but none of the isolates expressed resistance to ciprofloxacin. However, high resistance was observed for ampicillin (63.1\%), tetracycline (60.1\%), and cefuroxime (59.1\%). The varying antibiotic prevalence has been previously reported by Wogu and Ofuase [14] in a previous study on tomatoes in Benin City, Nigeria. The difference in resistance may be associated with varying functional groups of antibiotics and bacterial species. 
The presence of bacteria with antibiotic resistance associated with tomatoes sampled in this study highlights the potential risk of tomatoes to consumers.

\section{Conclusion}

The different bacterial species identified in this study suggest that bacteria contamination on tomatoes can be a potential risk to consumers. Such contamination can lead to food poisoning and food-borne illnesses. As a result, efforts should be made by consumers to discourage purchasing spoilt tomatoes from local markets in Accra as they can predispose vendors and the general public to infection.

\section{Recommendations}

To prevent any outbreak of diseases, tomatoes should be thoroughly washed with clean water and disinfected before use or properly cooked before consumption.

If possible, consumption of raw or partially cooked tomatoes in the form of sandwich or salads should be avoided, since it can predispose consumers to bacterial infections.

The environment in which the tomatoes are sold should also be kept clean since most of the bacteria isolated are associated with dirty environment. Tomato farmers as well as other vegetable farmers should be advised to avoid the use of contaminated wastewater for irrigation during cultivation.

\section{Limitations}

The current study had certain limitations; only a few tomatoes were sampled due to poor cooperation of vendors and some farmers (when approached). The results of this study cannot be generalized to all tomatoes sold in Ghana as variations in seasons, handling, harvesting, and postharvesting practices are different in many regions in Ghana. Other limitations include lack of baseline data on handling practices of vendors and farmers and as a result it is impossible to determine the source of the microorganisms detected in this study. A larger survey that will incorporate farms, farmers, and vendors to determine the sources of contamination and other variables is planned pending appropriate funding.

\section{Data Availability}

The datasets used and/or analysed during the current study are available from the corresponding author upon reasonable request.

\section{Conflicts of Interest}

The authors declare that there are no conflicts of interest regarding the publication of this paper.

\section{Authors' Contributions}

Forson Akua Obeng conceived and designed the experiments and draft of the manuscript, Pokuaa Belinda Gyasi performed the experiments, Michael Olu-Taiwo contributed reagents/materials/analysis tools, and F. Patrick Ayeh-Kumi conceived the study and participated in its design and coordination.

\section{References}

[1] G. N. Agrios, Plant Pathology, Academic press, New York, NY, USA, 4th edition, 2005.

[2] A. M. Valadez, K. R. Schneider, and M. D. Danyluk, "Outbreaks of foodborne disease associated with tomatoes," Tech. Rep. FSHN 12-08, 2012, http://edis.ifas.ufl.edu/fs192.

[3] K. L. Bradley, Horticultural News \& Research Journal, The University of Arizona Press, 2003.

[4] B. B. Freeman and K. Reimers, "Tomato consumption and health: emerging benefits," American Journal of Lifestyle Medicine, vol. 5, no. 2, pp. 182-191, 2011.

[5] . Mariga I. K., "Nutritional assessment of a traditional local vegetable (Brassica oleracea var. acephala)," Journal of Medicinal Plants Research, vol. 6, no. 5, 2012.

[6] Z. Lemma, W. Dawit, M. Negari, A. Chaka, T. Selvaraj, and G. Gebresenbet, "Identification of post-harvest rotting microorganisms from tomato fruits (Solanum esculentum Mill.) in Toke Kutaye District of West Shoa Zone, Ethiopia," Journal of Stored Products and Postharvest Research, vol. 5, no. 3, pp. 14-19, 2014.

[7] C. B. Behravesh, D. Blaney, C. Medus et al., "Multistate outbreak of Salmonella serotype Typhimurium infections associated with consumption of restaurant tomatoes, USA, 2006: Hypothesis generation through case exposures in multiple restaurant clusters," Epidemiology and Infection, vol. 140, no. 11, pp. 2053-2061, 2012.

[8] B. J. Akinyele and C. O. Akinkunmi, "Fungi associated with the spoilage of berry and their reaction to electromagnetic field," Journal of Yeast and Fungal Research, vol. 3, no. 4, pp. 49-57, 2012.

[9] M. Barth, T. R. Hankinson, H. Zhuang, and F. Breidt, "Microbiological spoilage of fruits and vegetables," in Compendium of the Microbiological Spoilage of Foods and Beverages, Springer, New York, NY, USA, 2009.

[10] A. K. Yeboah, A survey on postharvest handling, preservation and processing methods of tomato (Solanum lycopersicum) in the Dormaa and Tano South Districts of the Brong Ahafo Region of Ghana. [Doctoral dissertation], 2011, http://ir.knust.edu.gh/ xmlui/handle/123456789/2079.

[11] R. A. Baiyewu, N. A. Amusa, O. A. Ayoola, and O. O. Babalola, "Survey of the postharvest diseases and aflatoxin contamination of marketed pawpaw fruit (Carica papaya L) in South Western Nigeria," African Journal of Agricultural Research, vol. 2, no. 4, pp. 178-181, 2007.

[12] A. Ajayi, "Nature of Tomatoes Microflora under Storage," American Journal of Experimental Agriculture, vol. 3, no. 1, pp. 89-101, 2013.

[13] R. K. Garg, N. Batav, N. Silawat, and R. K. Singh, "Isolation and identification of pathogenic microbes from tomato puree and their delineation of distinctness by molecular techniques," Journal of Applied Biology \& Biotechnology, vol. 1, no. 4, pp. 2431, 2013.

[14] M. D. Wogu and O. Ofuase, "Microorganisms responsible for the spoilage of tomato fruits, Lycopersicum esculentum, sold in markets in Benin City, Southern Nigeria," School of Academics and Journal of Biosciences, vol. 2, no. 7, pp. 459-466, 2014. 
[15] F. Ogundipe, F. Bamidele, A. Adebayo-Oyetoro, O. Ogundipe, and O. Tajudeen, "Incidence of Bacteria with Potential Public Health Implications in Raw Lycopersicon esculentum (Tomato) Sold in Lagos State, Nigeria," Nigerian Food Journal, vol. 30, no. 2, pp. 106-113, 2012.

[16] O. C. Ugwu, F. O. Chukwuezi, and V. E. O. Ozougwu, "Microbial Agents of Tomato Spoilage in Onitsha Metropolis," Advance in Biology Research, vol. 8, no. 2, pp. 87-93, 2014.

[17] M. Cheesbrough, District Laboratory Practice in Tropical Countries, University of Cambridge, Cambridge, UK, 2nd edition, 2005.

[18] CLSI, Performance Stardards for Antimicrobial Disk Diffusion Tests. Approved Stardard, CLSI documents MO2, Clinical and Laboratory Stardards Institutes, Wayne, PA, USA, 12th edition, 2015.

[19] B. VE and A. C, "Antibiotic Practices and Factors Influencing the Use of Antibiotics in Selected Poultry Farms in Ghana," Journal of Antimicrobial Agents, vol. 2, no. 2, 2016.

[20] EUCAST, European Society of Clinical Microbiology and Infectious Diseases) Break points for Enterobacteriaceae, 2016, http:// www.eucast.org/eucast_news/news_singleview/?tx_ttnews\% 5Btt_news\%5D=202\&amp;cHash=293d9a5275c1647c230f7cc73a28a56f.

[21] L. R. Beuchat, "Vectors and conditions for preharvest contamination of fruits and vegetables with pathogens capable of causing enteric diseases," British Food Journal, vol. 108, no. 1, pp. 38-53, 2006.

[22] J. W. Buck, R. R. Walcott, and L. R. Beuchat, "Recent Trends in Microbiological Safety of Fruits and Vegetables," Plant Health Progress, vol. 4, no. 1, p. 25, 2003.

[23] MP. Falomir, D. Gozalbo, and H. Rico, "Coliform bacteria in fresh vegetables: from cultivated lands to consumers," in Current Research, Technology and Education Topics in Applied Microbiology and Microbial Biotechnology, pp. 175-1181, 2, 1751181, 2010.

[24] S. Brisse, F. Grimont, and P. A. Grimont, "The genus Klebsiella," in The Prokaryotes, 196, p. 159, Springer, New York, NY, USA, 2006.

[25] D. C. Pigott, "Foodborne Illness," Emergency Medicine Clinics of North America, vol. 26, no. 2, pp. 475-497, 2008.

[26] B. C. Adebayo-Tayo, N. N. Odu, C. U. Esen, and I. O. Okonko, "Microorganisms associated with spoilage of stored vegetables in Uyo metropolis, AkwaIbom state, Nigeria," Nature and Science, vol. 10, no. 8, 2012.

[27] A. Adeleke, "Public health risks associated with apples and carrots sold in major markets in Osogbo, Southwest Nigeria," Journal of Toxicology and Environmental Health Sciences, vol. 4, no. 8, pp. 140-144, 2012.

[28] E. Etebu, A. B. Nwauzoma, and D. D. S. Bawo, "Postharvest spoilage of tomato (Lycopersiconesculentum Mill.) and control strategies in Nigeria," Journal of Biology, Agriculture and Healthcare, vol. 3, no. 10, pp. 51-61, 2013.

[29] F. M. Mahamud, D. B. Dangora, S. Mu'azu, A. U. Khan, S. Nura, and Z. A. Gaiya, "Bio-chemical characterization of bacterial flora associated with spoilt vegetables in kaduna markets Northern Nigeria," Advances in Biological Chemistry, vol. 03, no. 01, pp. 141-145, 2013.

[30] K. O. Obieze, C. N. Obuagu, B. E. Asikong, A. E. Onyido, and B. A. Ogolo, "Bacteriological study of vegetables from markets of Calabar Cross-River State South Eastern Nigeria," The Internet Journal of Public Health, vol. 1, no. 2, 2011.
[31] E. Frenod, "Existence result for a model of Proteus mirabilis swarm," Differential and Integral Equations, vol. 19, no. 6, pp. 697-720, 2006.

[32] E. C. Chuku, D. N. Ogbonna, B. A. Onuegbu, and M. T. V. Adeleke, "Comparative studies on the fungi and bio-chemical characteristics of snake gourd (Trichosanthes curcumerina Linn) and tomato (Lycopersicon esculentus Mill) in Rivers State, Nigeria," Journal of Applied Sciences, vol. 8, no. 1, pp. 168172, 2008.

[33] F. Rahman and R. Noor, "Prevalence of pathogenic bacteria in common salad vegetables of Dhaka metropolis," Bangladesh Journal of Botany, vol. 41, no. 2, pp. 159-162, 2012. 


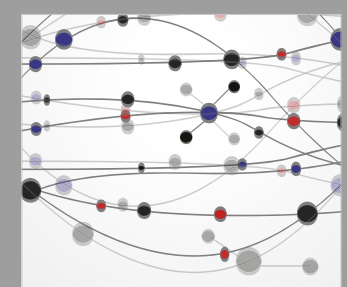

The Scientific World Journal
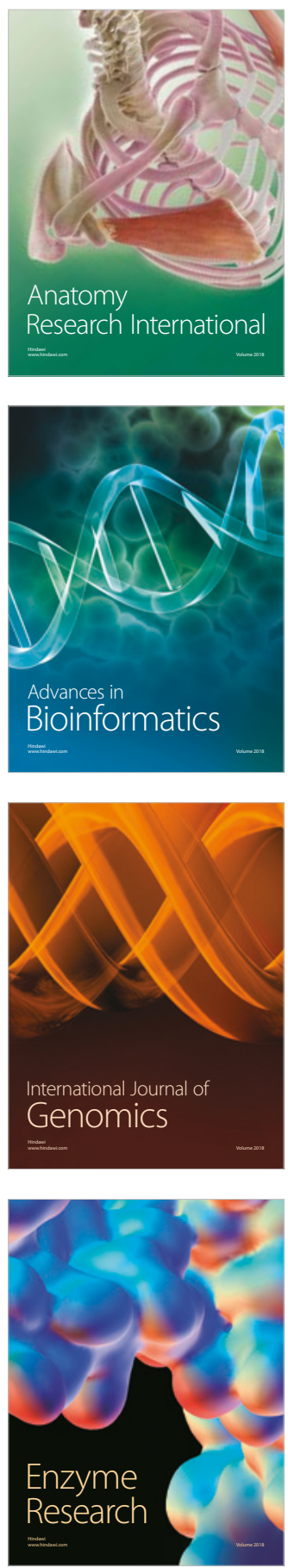
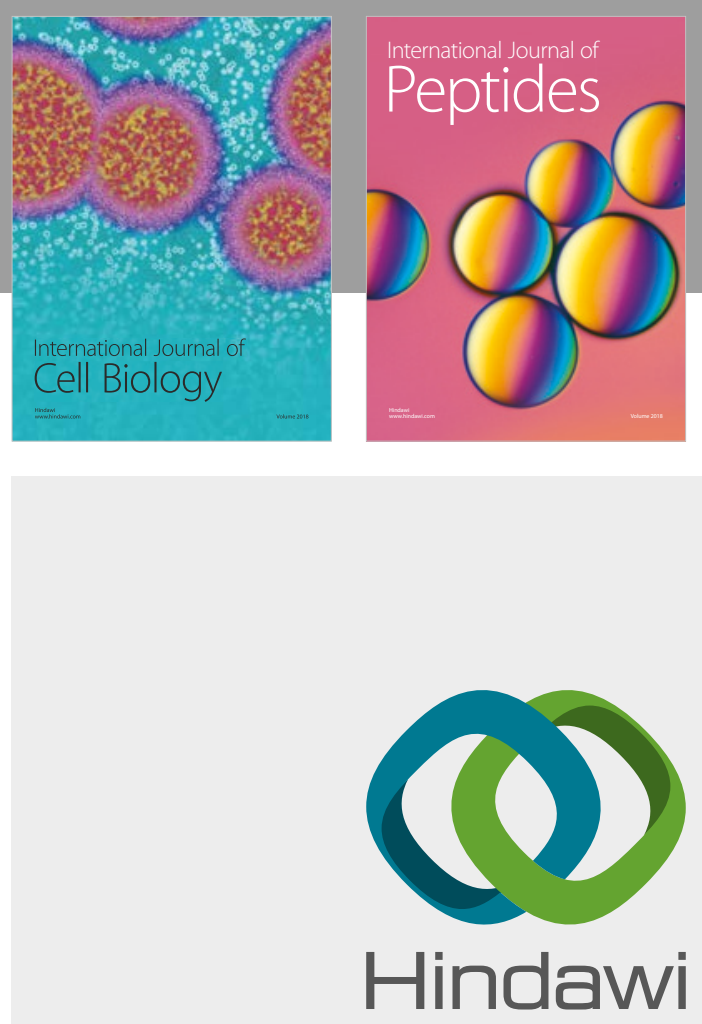

Submit your manuscripts at

www.hindawi.com
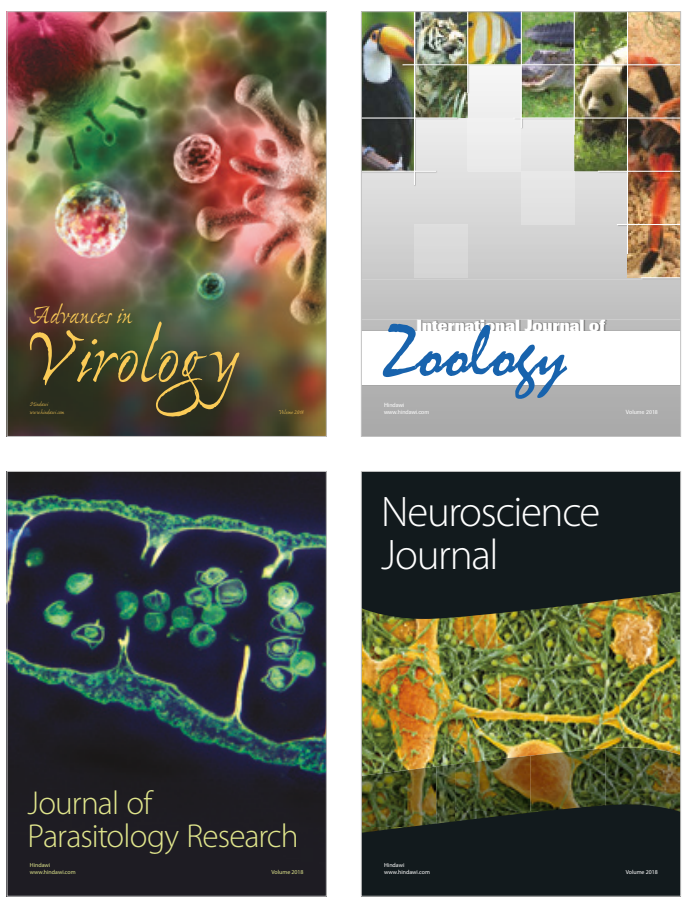
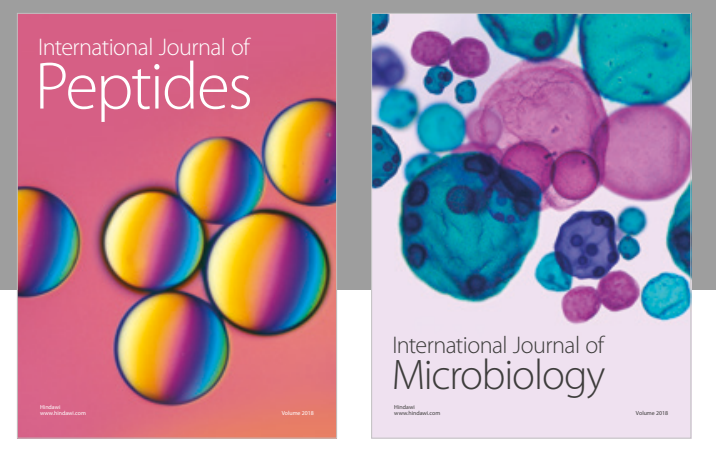

nternational Journal of Microbiology
Journal of
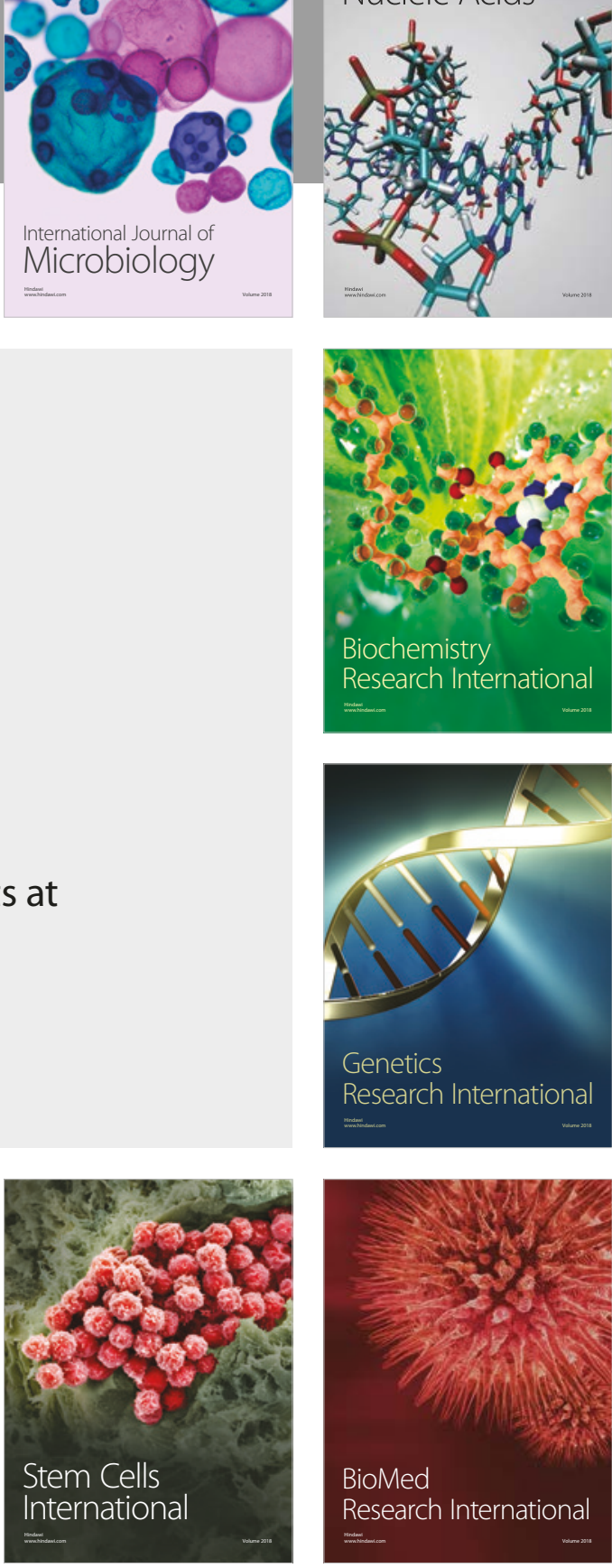
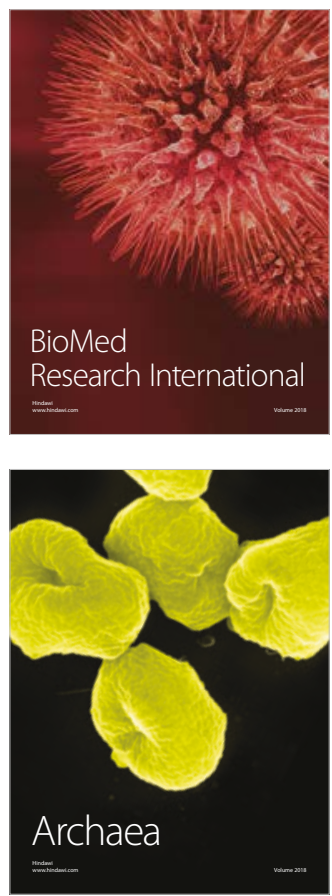